\title{
Guaranty Funds, Government Shareholding and Risk Taking: Evidence from China
}

\author{
Shi Hong ${ }^{\mathrm{a}}$ and Shizhe Bao ${ }^{\mathrm{b}}$ \\ ${ }^{a}$ Department of Social Security and Risk Management, School of Public Affairs, Zhejiang University, \\ 866 Yuhangtang Rd, Xihu District, Hangzhou, Zhejiang 3100058, China. \\ ${ }^{\mathrm{b}} \mathrm{School}$ of Information and Electronic Engineering, Zhejiang University of Science and Technology, Hangzhou, \\ 310023, China. \\ E-mail: hongshi@zju.edu.cn
}

This study examines the risk-subsidy, monitoring and ownership structure hypotheses in relation to guaranty funds using a sample from the Chinese insurance industry. Compared to the American model, Chinese insurance guaranty funds possess the following distinct features: preassessment, separate accumulation and partial responsibility for peer bankruptcy. We find that the risks of insurance firms decline following the establishment of guaranty funds. Pre-assess ment provides a limited risk incentive to insurers and one that is easily offset by stakeholder monitoring. In terms of the ownership structure hypothesis, we find that foreign insurers are more risk-driven than their state-controlled counterparts. Our findings have implications for countries striving to lessen the adverse effect of guaranty funds as well as for the improvement of insurance regulation policy in China.

The Geneva Papers (2015) 40, 653-677. doi:10.1057/gpp.2015.19

Keywords: guaranty funds; government shareholding; risk taking

Article submitted 7 December 2013; accepted 9 June 2015; published online 9 September 2015

The online version of this article is available Open Access

\section{Introduction}

As a safety net for policyholders, guaranty funds play a vital role in protecting policyholders when insurers become insolvent. It has been reported that over US\$56 billion were paid out in claims during the period 2001-2004 in the U.S. ${ }^{1}$ Guaranty funds can be viewed as providing a put option on the value of the insurer's assets with a strike price equal to the value of the policies. ${ }^{2}$ The institutional details of guaranty funds (e.g. coverage level, funding and premium systems) have the potential to create competing incentives for risk taking by insurers. Lee et al. ${ }^{3}$ first proposed the risk-subsidy and monitoring hypotheses for the establishment of guaranty funds. Their evidence shows that the risk to an insurer's asset portfolio increases after the enactment of a guaranty fund, and the increase in risk is significant only for stock insurers. Downs and Sommer ${ }^{4}$ support the risk-subsidy hypothesis and demonstrate a relationship

\footnotetext{
${ }^{1}$ National Conference of Insurance Guaranty Funds (2011).

2 Merton (1977).

${ }^{3}$ Lee et al. (1997).

${ }^{4}$ Downs and Sommer (1999).
} 
between insider ownership and risk taking. These empirical results were obtained in the context of American insurance guaranty funds. American insurance guaranty funds are characterised by risk neutrality and incorporate a post-insolvency assessment mechanism, ${ }^{5}$ which is considered to be essential for risk taking.

One solution to this problem could be to replace the current flat-rate guaranty fund charges with risk-based premiums, as suggested by Cummins. ${ }^{6}$ This would force insurers to bear the cost of their risk taking, even in the absence of market penalties for risk. ${ }^{7}$ However, few American guaranty fund associations have adopted this strategy.

In theory, pre-assessment is another way to mitigate the risk-subsidy incentive for insurers. In this scenario, an insolvent insurer has to pay part or even all of its bills from its ex ante accumulated guaranty fund. How does a guaranty fund with a pre-assessment mechanism perform in mitigating the risk incentive? As far as we know, no empirical study has yet examined this question. If a nation-specific empirical study shows that guaranty funds with pre-assessment are effective in reducing risk taking by insurers, and hence, that pre-assessment increases the efficiency of guaranty funds, this approach would become of interest to other nations.

Accordingly, this study tests the effect of a pre-insolvency assessment mechanism on risk taking, based on evidence from China. Chinese guaranty funds are characterised by preassessment and insurers taking partial responsibility for their bankrupt peers. We investigate whether the risk-subsidy incentive could be low enough to be offset by a monitoring incentive in guaranty funds with ex ante assessment. Secondly, we aim to further examine the ownership hypothesis by investigating whether there is any difference in the effect of guaranty funds on risk taking between state-controlled and foreign insurers. The former face some distinct governance challenges, such as politically motivated ownership interference, a complex chain of agents and so on. Meanwhile, it is often deemed that state-controlled insurers are protected from takeover and bankruptcy. Does the discrepancy in governance structures result in a difference in the effect of guaranty funds on risk taking?

Our study is original in two ways. Firstly, we believe we are the first to examine the effect of a guaranty fund with ex ante assessment on risk taking by insurers. Secondly, we use the difference in difference (DID) model to investigate the difference in the effect of guaranty funds between state-controlled and foreign insurers. DID is a quasi-experimental technique that measures the within-subject pre- and post-treatment difference between the treatment and control groups. To the best of our knowledge, no other study of guaranty funds has adopted this method. Our findings have implications for countries striving to lessen adverse effects by adjusting the institutional details of guaranty funds as well as for the improvement of insurance regulation policy in China.

The rest of the paper is organised as follows. The background and hypothetical development are introduced in the third section after a literature review in the next section; the latter section discusses the methodology and data; the conclusions are then set out in the final section following the presentation of the empirical results in the penultimate section.

\footnotetext{
5 According to the U.S. guaranty fund system, New York is the only state that has a pre-assessment guaranty fund based on the insurer's premium income in New York. It requires insurers to contribute to a permanent insolvency fund. All other states that have guaranty fund laws have post-assessment vehicles. There is a significant difference between Chinese guaranty funds and American guaranty funds with one exception. Therefore, the American guaranty funds compared in this study concern those established in states other than New York.

${ }^{6}$ Cummins (1988).

${ }^{7}$ Downs and Sommer (1999).
} 


\section{Review}

Guaranty funds can be viewed as providing a put option on the value of an insurer's assets with a strike price equal to the value of the insurance policies. ${ }^{2}$ It is argued that they provide risk-taking incentives for insurers and so may threaten the stability of the whole industry. However, proponents of guaranty funds argue that they are structured specifically to provide incentives for sound insurance companies to monitor their competitors and report unsafe practices to state regulators. They also suggest that such peer monitoring is more effective and can offset risk-taking incentives for insurers.

The empirical evidence for the impact of guaranty funds on insurers' risk taking and the potential for the fragility of the insurance sector is mixed. The three most-frequently cited studies all focus on American insurance guaranty funds. Munch and Smallwood ${ }^{8}$ examine insolvencies among property liability (PL) insurers around the establishment of the guaranty funds. They find evidence consistent with the monitoring hypothesis that guaranty funds operations have reduced insolvencies. Lee $e t a l .^{3}$ also examine changes in PL insurers' risk taking around the enactment of state guaranty fund laws. However, their evidence shows that the risks of insurers' asset portfolios increase following enactment. Moreover, they propose the ownership structure hypothesis, which suggests that managers of stock insurance firms have stronger incentives to increase asset risk than managers of mutuals since the latter bundle ownership claims with their insurance policies. They also find evidence that the risk increase for stock insurers is higher than that of mutuals.

Downs and Sommer ${ }^{4}$ further examine the competing effects of the risk-subsidy and monitoring hypotheses for stock insurers. Agency theory proposes that managers of firms will often act in their own interests rather than those of shareholders, for the long-term value of the nondiversifiable, firm-specific human capital of managers may be maximised by ensuring firm survival rather than seeking to maximise value. One of the ways to reduce the conflict between firm owners and managers is by giving the latter an ownership stake, since this aligns their mutual interests more closely. Downs and Sommer ${ }^{4}$ suggest that the implicit put option created by guaranty funds would benefit the stockholders of PL insurers as well as managers with an ownership interest. Their empirical results support the risk-subsidy hypothesis and demonstrate the essential link between insider ownership and risk taking. Moreover, the extent to which managers engage in risk taking may depend on how well their interests are aligned with those of the owners.

American insurance guaranty funds are characterised by a flat rate and an ex post assessment system, both of which are deemed essential risk-taking incentives for insurers. Chinese insurance guaranty funds are pre-assessed, which is similar to the deposit insurance system in many countries. ${ }^{9}$ The availability of $e x$ ante funding may ensure faster payout, provide greater reassurance to policyholders about the guaranty fund's ability to meet its commitments, help avoid the procyclicality arising from raising premiums for surviving

\footnotetext{
${ }^{8}$ Munch and Smallwood (1980).

${ }^{9}$ Among Financial Stability Board (FSB) member jurisdictions with an explicit deposit insurance system, a considerable number (16 countries) have built up an ex ante fund in response to a growing trend in funding patterns around the world. Five jurisdictions (Australia, Italy, Netherlands, Switzerland and the U.K.) are presently supported solely by an ex post funding system, although the Netherlands shifted to an ex ante system in 2012, and Italy and the United Kingdom are actively considering this option (Financial Stability Board, 2012).
} 
656

insurers following an insurer failure, and contribute to fairness by imposing a cost burden on a failed insurer. On the other hand, ex ante funding implies the higher administrative costs associated with the collection of premiums and fund management.

Theoretically, ex ante assessment would also mitigate the risk-taking incentives for financial institutions such as banks. Many studies have looked at the effect of deposit insurance with ex ante funding on banks' risk taking. For example, Wheelock and Wilson ${ }^{10}$ and Alston et al. ${ }^{11}$ find no relationship between historical U.S. bank failure rates and deposit insurance. Karels and McClatchey ${ }^{12}$ also find no evidence that the adoption of deposit insurance has increased the risk taking of U.S. credit unions. However, Gropp and Vesala ${ }^{13}$ show that the introduction of explicit deposit insurance in the European Union (EU) may have significantly reduced banks' risk taking. Conversely, Demirgüç-Kunt and Detragiache ${ }^{14}$ looking at a sample of 61 countries, find that, from 1980 to 1997, the adoption of deposit insurance significantly increased the probability of a banking crisis in the country. Penas and Ioannidou ${ }^{15}$ compare the risk-taking effect of ambiguous implicit guarantees and explicit deposit insurance in conditions of flat insurance premiums and partial coverage for all depositors. They find that during the post-deposit insurance period, banks are more likely to initiate loans they know are riskier (i.e. loans with worse internal ratings at origination). Angkinand and Wihlborg ${ }^{16}$ study the relationship between the risktaking behaviour and governance of banks following the establishment of deposit insurance. Their results show that the U-shaped relationship between their proxies for risk taking and explicit deposit insurance coverage is robust when governance variables are introduced. State ownership and shareholder rights seem to have a significant effect on risk taking through market discipline, while foreign ownership does not.

Studies on the insurance industry show that governance structure is essential to risk taking by insurers. Ho et al. ${ }^{17}$ examine the impact of organisational structure and board composition on risk taking in the U.S. property casualty insurance industry. They find that some board composition variables not only have an impact on risk-taking behaviours but also affect particular risk measures differently. Cheng et al. ${ }^{18}$ investigate the relationship between the risk taking by life and health (LH) insurers and the stability of their institutional ownership using a simultaneous equation system model, and find that stable institutional ownership is associated with lower total risk.

Empirical evidence for the impact of deposit insurance (or a guaranty fund) on financial institutions (bank or insurer) risk taking is mixed. The design of the deposit insurance (or guaranty fund) scheme and the institutional framework has attracted increasing interest from researchers in recent years. Our study provides insight into the practical effect of preassessment , a topic not so far examined in the field of guaranty fund studies. Moreover, our

\footnotetext{
${ }^{10}$ Wheelock and Wilson (1995).

${ }^{11}$ Alston et al. (1994).

${ }^{12}$ Karels and McClatchey (1999).

${ }^{13}$ Gropp and Vesala (2004).

14 Demirgüç-Kunt and Detragiache (2002).

15 Penas and Ioannidou (2008).

${ }^{16}$ Angkinand and Wihlborg (2010).

${ }^{17}$ Ho et al. (2013).

${ }^{18}$ Cheng et al. (2011).
} 
investigation of the relationship between government shareholding and the effect of guaranty funds on risk taking will help to improve guaranty fund policy and operations.

\section{Background and hypothesis development}

\section{Implicit and explicit Chinese guaranty funds}

Over the past two decades, the Chinese insurance industry has undergone the process of reform from a planned to a market-oriented economy. With China's admission to the World Trade Organization (WTO) in 2001, the insurance industry was opened up still further to foreign companies. The removal of regional and business restrictions created an equally competitive environment for both domestic and foreign insurers. In order to seize market share, domestic insurance companies adopted a "volume expansion" strategy that resulted in severe problems. ${ }^{19,20}$ In the meantime, state-owned insurance companies went through a corporatisation reform and began to be more focused than before on profitability.

In order to enhance the role of market discipline and facilitate an effective exit mechanism, the Chinese Guaranty Fund Regulation was enacted in 2004 and came into force in $2005 .^{21}$ According to the Insurance Law (1995), Chinese guaranty funds had been established in 1995. However, during the period from 1995 to 2004, no explicit guaranty funds were established, although every insurer in business in China was required to collect a special reserve which was referred to as a "guaranty fund". Insurers held this collection within their own companies and no details were given about the recovery of policyholders' claims, such as eligibility, benefit cap or the assurance that the reserve would be available and sufficient in case of insurer failure.

The absence of such explicit guarantees led to strong expectations that the government and regulators would respond by issuing blanket guarantees for all policyholders or by bailing them out if an insurance company became financially troubled or was no longer able to uphold its end of the bargain. Such expectations turned into a belief, prevalent among domestic insurers and their customers (even those who were government officials), that the

\footnotetext{
${ }^{19}$ Sun (2003).

${ }^{20}$ While total premiums experienced rapid growth, severe problems also arose; low per capita productivity, high operations costs, imprudent risk taking, insufficient capital, lack of innovation, shortage of professional personnel, consumer distrust and reputational damage. In addition, insurance personnel have been trained to compete for market share and premium volume only. They often do not consider service, innovation or profitability.

21 The Amendment of the Guaranty Fund Regulations was enacted in 2008. The trigger for this was the use of guaranty funds by the China Insurance Regulatory Commission (CIRC) to save the New China Life Insurance Company (NCI). The chairman of NCI had misappropriated over 13 billion yuan of company funds to his interest-related partners to enable them to purchase NCI shares and keep control of the company. In 2006, in order to improve the corporate governance of NCI, CIRC decided to purchase NCI shares from those interestrelated partners by using the guaranty fund. Thus, the Insurance Guaranty Fund held 38.8 per cent of NCI shares and became the biggest shareholder. This event aroused heated nationwide discussion over whether or not the purpose of the guaranty fund was to protect policyholders' interest or to save an insurer, and whether it was legitimate for CIRC as a government department to have intervened in this manner with a private company. One of the main amendments to the regulations was the establishment of the China Insurance Security Fund Corporation in 2008 to take charge of guaranty funds.
} 
government would ultimately take responsibility for keeping insurers sound. From this perspective, Chinese domestic insurers and policyholders had the protection of an implicit guaranty fund.

Following the establishment of an explicit guaranty fund, all policyholders are now protected, whether their underwriting company is domestic or foreign. Chinese guaranty funds have some of the same features as those in other countries, such as a benefit cap for policyholders, flat-rate assessment, and the exclusion of reinsurance and overseas business. However, compared to the American model, Chinese guaranty funds have the following special features: (1) pre-assessment: The guaranty fund of each insurance firm operating in China is pre-assessed by the China Insurance Security Fund Corporation; (2) the guaranty funds collected from each insurer are not pooled before use, so funds are accumulated under a nominal account for each insurer and firms can suspend their responsibility for collection when the accumulation reaches 6 per cent of their total asset base; and (3) partial responsibility for peer bankruptcy: when an insurer gets into financial trouble or goes bankrupt, policyholders' outstanding claims are first recovered from the funds accumulated in its nominal account. If this does not achieve full recovery, peers are then responsible for the shortfall, based on their percentage of market share.

It is proposed that the discrepancies between the institutional details of guaranty funds and the structure of the insurance industry will result in the funds having different effects on risk taking by insurers.

\section{Hypothesis development}

In the Chinese guaranty funds, the flat-rate assessment system means insurers with lower risks collect more funds, relative to their real risks, and vice versa for higher-risk insurers. A flat-rate assessment therefore provides a risk incentive to insurance companies. On the other hand, the requirement to share responsibility for peer bankruptcy and the preassessment system are both supposed to weaken the risk-taking incentive compared to American guaranty funds. The ex ante funding system and the separate fund accumulation means each insurer has to shoulder all or at least most of the cost of excessive risk. With the decline in the implicit put option value of guaranty funds, the risk-taking incentive for insurance companies decreases. Therefore, the risk incentive of the Chinese guaranty funds exists in theory, but is limited in practice.

In terms of monitoring incentives, Lee et al. ${ }^{3}$ consider these to be much less than stated in American guaranty funds for regulators, competitors and customers. We assume the monitoring incentive for the Chinese guaranty funds will be weak based on their institutional properties. Firstly, monitoring by peer companies would not be effectively stimulated after the establishment of explicit guaranty funds because of the partial responsibility requirement and the standard free-rider problems. Secondly, monitoring by policyholders will be limited for two reasons: (1) policyholders are adequately protected by the Insurance Law when an insurer goes bankrupt ${ }^{22}$ and (2) limited public awareness of the issues and restricted access to

${ }^{22}$ It is stipulated in the Insurance Law that, when an insurer goes into liquidation, policyholders are second in line to receive satisfaction and their outstanding claims must be recovered from the liquidation assets. Furthermore, when a life insurance company gets into financial trouble, all pending liability and outstanding claims will be taken over by another life insurer. 
information prevent policyholders from monitoring insurers effectively. Nowadays, most individual Chinese policyholders have no real idea about guaranty funds. It is also hard for them to obtain the information necessary to conduct monitoring because Chinese insurance firms, with the exception of a few listed companies, are not required to disclose information timeously or regularly to the public. As for monitoring from regulators, the establishment of guaranty funds may stimulate them to pay more attention to insurers, especially the bigger companies. However, as a whole, the monitoring incentives for regulators, competing insurers and customers are likely to be weak.

What is the net effect of the risk-subsidy incentive and monitoring following the establishment of Chinese guaranty funds, since both are theoretically weak? Is the risktaking incentive weak enough to be offset by monitoring by stakeholders and regulators? We propose the following two hypotheses.

H1: The net effect of the establishment of explicit Chinese guaranty funds on risk taking by insurers will be a risk incentive.

H2: The net effect of the establishment of explicit Chinese guaranty funds on risk taking by insurers will be a monitoring incentive when monitoring from stakeholders dominates.

Next, we investigate the relationship between risk taking and ownership structure following the establishment of guaranty funds. The ownership identities of insurance firms can be classified into two groups: state-controlled and foreign. We define domestic insurers controlled by the state by means of full, majority or significant minority ownership as statecontrolled insurers, and all others as foreign insurers. Chinese governments throughout the years have directly or indirectly invested in most of the current domestic insurance companies. In practice, the China Investment Corporation, local government, the State Asset Management Bureau, government bureaux and state-owned enterprises are the most common investors in domestic insurers.

Risk-taking strategies differ between state-controlled and foreign insurers due to the discrepancy in governance structures. State-controlled insurers have faced some distinctive governance challenges. Firstly, they have suffered from excessive hands-on, politically motivated interference from owners. Their risk strategy is therefore determined not only by the market but also by political objectives. The multiple and sometimes contradictory objectives of state ownership result in the state intervening excessively in matters or decisions which should be left to the company and its own governance entities. ${ }^{23}$ Secondly, statecontrolled insurers involve a complex chain of agents (management, board, ownership entities, ministries and the government) with a lack of clearly and easily identifiable principals. This makes it difficult to evaluate their performance and impose accountability. ${ }^{24,25}$

\footnotetext{
${ }^{23}$ For example, Chinese government officials are appointed as senior managers of state-controlled insurers and supervised by the Organisation Department of the Central Committee of the Communist Party of China (CPC). Ensuring the realisation of the objectives specified by government investors would maximise the long-term value of the nondiversifiable human capital.

${ }^{24}$ To structure this complex web of accountabilities in order to ensure efficient decisions and good corporate governance in state-controlled insurers is a challenge (OECD, 2005).

25 OECD (2005)
} 
660

On the other hand, it is often said that state-controlled insurers are protected from two of the major threats to private sector corporations, namely takeover and bankruptcy. A guaranty fund as a put option has less value to a state-controlled insurer than to a foreign company. State-controlled insurers are therefore likely to have little risk incentive following the establishment of explicit guaranty funds.

Meanwhile, foreign insurers have suffered from tough competition for market share and face certain disadvantages, such as having fewer branches and being less well known to the public. Accordingly, they have to use more risky strategies to seize market share. The establishment of explicit guaranty funds provides some protection against such risk taking. Therefore, foreign insurers are likely to be more affected by the establishment of guaranty funds.

We propose the following hypothesis regarding the effect of explicit guaranty funds on risk taking by insurers on the basis of ownership structure.

H3: With the establishment of explicit guaranty funds, foreign insurers would be more risk-driven than state-controlled insurers.

That is, risk taking by foreign insurers will decrease by less than that of state-controlled insurers if the net effect of a guaranty fund is to increase monitoring, and foreign insurers will take more risks than state-controlled firms if the net effect of guaranty funds is to create a risk incentive.

\section{Methodology and data}

\section{Explicit guaranty funds and risk taking}

This study examines the net effect of establishing Chinese guaranty funds on risk taking by insurers and the difference in any such effect between state-controlled and foreign insurers. Risk taking by insurers is affected by two important factors. One is the characteristics of the individual company such as size, age, risk preference and premium growth; the other is the macroeconomic environment, in terms of factors such as the growth of the economy and market concentration. These factors are used as control variables in our regression models.

Large insurance firms are expected to exhibit lower risks for several reasons. ${ }^{26,27}$ On the other hand, if financial institutions are perceived as "too big to fail", their risk taking might not be affected by guaranty funds or a deposit fund arrangement, as they enjoy a comprehensive safety net regardless. ${ }^{28} \mathrm{We}$ use the total assets of an insurance company as a proxy for firm size and the natural logarithm of the asset base as the size variable.

\footnotetext{
${ }^{26}$ Cheng et al. (2011).

${ }^{27}$ Firstly, they have greater access to derivatives markets for hedging and other risk-taking strategies and may be able to hedge at a lower cost due to their scale. Secondly, they have stronger incentives to protect their franchise values and to maintain their reputation for safety, because this enables them to market products such as guarantee services (e.g. performance bond guarantees, default guarantees for commercial papers and municipal revenue bonds (standby letters of credit)) and to price their products more favourably. Thirdly, investors may believe that regulators are unwilling to let larger insurers fail, in which case, the value of the implicit guaranty fund option increases with insurer size. This is similar to the notion of being "too big to fail" in the banking industry.

${ }^{28}$ Gropp and Vesala (2004).
} 
Firm age reflects an insurance company's ability to survive. For example, startups are prone to fail. Insurance companies with a long history are assumed to be more sophisticated at dealing with difficult market conditions and to be able to sustain stable growth through hard times.

Risk preference is determinative of insurers' risk strategy. A relatively conservative company will prefer to diversify in terms of products and geographic areas, as well as to carry a high level of reinsurance. Reinsurance as a conventional means of risk management creates a manageable and profitable portfolio of insured risks and makes the company's results more predictable. The variables used as proxies for insurers' risk preference in our models include the business line Herfindahl index, geographic Herfindahl index and the reinsurance ratio. The percentage of long-tail product lines is also used to capture PL insurers' risk preference.

$B H H I_{i t}$ (the business line Herfindahl index) measures the line concentration and indicates the level of risk taking. It is defined as $\sum\left(P W_{i} / T P W\right)^{2}$, where $P W_{i}$ is the value of the net written premiums in line $i$ and $T P W$ is the insurer's total net written premiums. $G H H I_{i t}$ (the geographic Herfindahl index) is a measure of geographic concentration and is defined as $\sum\left(P W_{i} / T P W\right)^{2}$, where $P W_{i}$ is the value of net written premiums in province $i$, and $T P W$ is the insurer's total net written premiums. ONGTAIL $_{i t}$ (percentage of long-tail lines) is calculated by the premiums of long-tail lines divided by total net written premiums. $R R_{i t}$ (the reinsurance ratio) is measured as the ratio of reinsurance ceded divided by the sum of direct premiums written plus reinsurance assumed. ${ }^{17}$

The macroeconomy has been found to be a key factor for growth in the insurance market ${ }^{29}$ and to be correlated with the probability of health insurance coverage. ${ }^{30}$ The speed of China's economic growth has caused a boom in the insurance market. Chinese insurance companies' optimistic expectations of this situation continuing may stimulate them to engage in risky behaviour. We use the growth rate of the gross domestic product (GDP) as a proxy for the macroeconomy.

In addition, market competition affects insurers' risk-taking strategies. In a monopoly or oligarchical monopoly market, insurers find it much easier to obtain profit and are less willing to take risks. In a competitive market, insurers have to develop strategies for retaining market share, and those facing tough competition may take risky measures such as promising unrealistically high commissions to agents or selling products on the basis of misleading information. The Herfindahl index is used as a proxy for market competition and is calculated as the sum of the squares of the market shares of all insurers writing business in the present year.

The regression model used to examine the effect of guaranty funds on risk taking is as follows:

$$
R_{i t}=c+\beta G F+X_{i t} \alpha+u_{i t},
$$

where $i$ denotes cross-sections; $t$ denotes time-periods with $i=1,2, \ldots, N ; t=1,2, \ldots, T ; c$ is the intercept, $\alpha$ is $K \times 1 ; X_{i t}$ is the $i t$-th observation on $K$ control variables; and $R_{i t}$ are the measures of risks. $G F$ is a dummy variable used as a proxy for the establishment of guaranty funds.

\footnotetext{
29 Outreville (1996).

${ }^{30}$ Cawley and Simon (2003).
} 
662

The Chinese Guaranty Fund Regulation was implemented in 2005. Therefore, as a binary variable, $G F$ takes the value of one for the years from 2005, and zero for the years before.

Accounting risk measures are used in this study, including total, underwriting and leverage risk. Total risk is defined as the standard deviation of the return on assets, following Ho et al. ${ }^{17}$ The measures of underwriting risks for PL and LH insurers are different. The proportion of premiums written in the health business can be used as a proxy for the underwriting risk for LH insurance firms, following Cheng et al. ${ }^{18}$ Health products are prone to more uncertainties than other products offered by an LH insurance company since life insurance, annuities and pensions can be predicted more reliably based on mortality tables. The proxy for the underwriting risk of PL insurers is the standard deviation of the loss ratio. The loss ratio is calculated by the sum of total losses incurred (paid and reserved) in claims plus adjustment expenses divided by total premiums earned. Insurers that consistently experience high loss ratios may be in bad financial health. Finally, the leverage risk is defined as one minus the surplus-to-asset ratio.

These three risk measures are used to depict the risks faced by an insurer from different perspectives. The underwriting risk refers to the risk of loss on underwriting activity. The leverage risk is related to the default risk $^{17}$ It should be noted that the appropriate leverage ratio is firm-specific. Larger insurers have more diversified portfolios and are likely to be able to afford higher leverage. Return on assets shows how efficient an insurer is at managing and using its assets to generate earnings. Underwriting profit and investment earnings are the two sources of net income. The standard deviation of the return on assets gives a picture of an insurer's comprehensive risk, while the underwriting and leverage risks measure specific risks arising from certain aspects of its operations.

\section{Government shareholding and risk taking}

The DID model is used to examine the difference in the effect of guaranty funds on risk taking by state-controlled and foreign insurers. DID is a quasi-experimental technique that measures the effect of a treatment at a given period in time. In contrast to a within-subject estimate of the treatment effect, which measures the difference in an outcome before and after treatment, or a between-subjects estimate of the treatment effect, which measures the difference in an outcome between the treatment and control groups, the DID estimator represents the within-subject, pre- and post-treatment differences for the treatment and control groups.

The model is specified as follows:

$$
R_{i t}=c+\beta_{1} G F+\beta_{2} G S+\beta_{3} G F^{*} G S+X_{i t} \alpha+u_{i t}
$$

where $i$ denotes cross-sections; $t$ denotes time-periods with $i=1,2, \ldots, N ; t=1,2, \ldots, T ; c$ is the intercept; $\alpha$ is $K \times 1 ; X_{i t}$ is the $i t$-th observation on $K$ control variables; and $R_{i t}$ are the measures of risks. $G F$ is a dummy variable used as a proxy for the establishment of guaranty funds. The dummy variable $G S$ is used as a proxy for ownership structure. $G S$ is zero for a state-controlled insurer and one for a foreign insurance company.

In this study, state-controlled insurers are regarded as the control and foreign insurers as the treatment group. State-controlled insurers have always been protected, whether by implicit or explicit guaranty funds. Foreign insurers have experienced a shift from nothing to 
explicit protection. The latter are therefore more likely to respond to the establishment of the explicit guaranty fund by taking risks than are their state-controlled counterparts.

\section{Data}

Our sample consists of $15 \mathrm{PL}$ and $13 \mathrm{LH}$ insurers approved to write business in China at the end of 2001. At that time, there were a total of 16 PL insurers and $15 \mathrm{LH}$ insurance firms operating business. In the LH insurance market, we exclude Xinjiang Jianshe Bintuan Company from our sample, for it was restructured as China United Property Insurance Company and withdrew from this sector in 2006. The PingAn Insurance Company, as a group, is excluded from both the PL and LH insurance markets because no separate balance sheet is provided for the respective segments of its business. Table 1 shows all the insurance companies approved to write business in China in 2001. Our sample includes all of them except for the three insurers whose names are shown in italics.

The data spans the period from 2001 to 2007 . We choose this period to enable a relatively consistent phase in the development of the insurance industry. Firstly, China became a member of the WTO in 2001. With the implementation of China's commitment to the WTO, regional and business restrictions were removed, resulting in a more evenly competitive market for foreign companies than before. Secondly, the financial crisis in 2008 significantly affected the Chinese insurance market and its regulation. China's insurance regulators increased their supervision, and insurance companies have actively implemented conservative risk management strategies since then.

The market shares of the PL insurers in the sample are all over 70 per cent whereas those of the LH insurers are around 70 per cent during the sample period (see Table 2).

The data comes from the China Insurance Year Books, China Insurance Regulatory Commission and the China Statistical Yearbooks. We measure the standard deviation of the return on assets and loss ratios by using five-year rolling period data. Some measures therefore include information obtained before the establishment of explicit guaranty funds. For example, the risk measure for 2007 is based on information extending back to 2003. Our data is also an unbalanced panel, given that a few of the foreign insurance companies are newcomers to the market. The total and underwriting risks of an insurer cannot be measured in 2001 and 2002 by using five-year rolling period data when that firm was only established in 1999.

As is well known, the error terms of a panel analysis are likely to be correlated over time and across firms, and unobserved firm-specific components are likely to be correlated with observable firm characteristics or explanatory variables. This could lead to biased coefficient estimates. In our specification of the error components, we take the disturbances as:

$$
u_{i t}=u_{i}+v_{i t},
$$

where $u_{i}$ are cross-section-specific components and $v_{i t}$ are remainder effects.

We conduct a heteroscedasticity test of the sample data, given that larger insurance firms are expected to take fewer risks. The result of the White test shows that heteroscedasticity is present. The Hausman test reveals that the fixed-effects model is preferred.

A correlation test of independent variables is also conducted. We exclude some highly correlated control variables from our models. However, the omission of variables may result in an endogeneity problem. We discuss the endogeneity issues of the ownership structure and risk taking further below. 
Table 1 Companies approved to underwrite insurance in China in 2001

\begin{tabular}{ll}
\hline PL insurance market & LH insurance market \\
\hline PICC & China Life \\
Pacific Property & Pacific Life \\
Xinjiang Jianshe Bintuan (China United) & Xin Hua (New China) \\
Hua Tai & Taikang \\
Sinosafe & Zhonghong \\
Dazhong & Pacifi-Aetna \\
YongAn & Allianz Dazhong \\
TianAn & AXA-China Minmentals \\
Tokio Marine-Shanghai & John Hancock-TianAn \\
AIU-Shanghai & AIA-Shanghai \\
AIU-Guangzhou & AIA-Guangzhou \\
AIU-Shenzhen & Prudential \\
Royal\&Sun-Shanghai & Taiping Life \\
Winterthur (Switzerland)-Shanghai & China GMG \\
MinAn-Shanghai & Xinjiang Jianshe Bintuan \\
MinAn-Haikou & PingAn \\
MSIG-Shanghai & \\
Federal-Shanghai & \\
PingAn & \\
\hline
\end{tabular}

Data source: China Insurance Yearbook 2002.

Table 2 Market shares of sample PL and LH insurers 2001-2007

\begin{tabular}{llllllll}
\hline & 2001 & 2002 & 2003 & 2004 & 2005 & 2006 & 2007 \\
\hline PL insurers & 0.91 & 0.89 & 0.88 & 0.87 & 0.83 & 0.77 & 0.76 \\
LH insurers & 0.72 & 0.76 & 0.71 & 0.73 & 0.69 & 0.72 & 0.70 \\
\hline
\end{tabular}

The Durbin-Wu-Hausman (DWH) test is used to examine the potential endogeneity issue of the ownership structure variable. In the first stage, the variable is regressed against all the exogenous and instrumental variables. In the second stage, the residual of the endogenous variable is added to the original regression model. If the coefficient of the residual of ownership structure variable is statistically significant, that variable can be considered endogenous.

We choose the location of the firm's head office as the instrumental variable for ownership structure. Most Chinese insurance companies have their head office in either Beijing or Shanghai. Beijing is the political centre of China, while Shanghai is an international financial city. The resource dependence theory (RDT) proposes that external resources are an important tenet of both the strategic and tactical management of any company. Organisations depend on resources, and these are ultimately found in the external environment. We find that most state-controlled insurers have their head offices in Beijing, while most foreign insurers choose Shanghai. LC is denoted as an instrumental variable for GS and defined as the location of the head office when the insurance company was set up. LC is zero if the head office was located in Beijing at the time of establishment, and one if the head office was located in Shanghai or elsewhere. 
The endogeneity test results show that ownership structure is an endogenous variable. Then, we test the strength of the instrumental variable LC and find that the F-statistics against the null hypothesis (that the excluded instruments are irrelevant in the first-stage regression) are all larger than 10, which validates the correlation of ownership structure and instrumental variable. The assumption that the instrument is not correlated with the error term is not testable in our exactly identified model. However, it may reasonably be inferred that the location of the head office when an insurance company was established has little relationship with its subsequent risk-taking behaviour.

Next, we use the two-stage least square (2SLS) method to address the endogeneity issue in Model 2.

In a DID model, the validity of the DID estimator is based on the assumption that the underlying trend in the outcome variable will be the same for both treatment and control groups. We test the Ashenfelter dip of the data to ensure the validity of our DID model. In our study, guaranty funds are nationwide and each insurer is assessed. Therefore, the potential bias caused by Ashenfelter' dip is nonexistent. ${ }^{31}$

We first regress Models 1 and 2 using the pooled sample. Model 1 uses the fixed-effects model and Model 2 is the 2SLS regression. The heteroscedasticity-robust $t$-test is applied. Then, we separate the pooled sample into PL and LH subsamples to enable the measurement of the underwriting risks of each type of insurer, and regress the models individually.

Table 3 presents the descriptive statistics of major variables depicting the individual properties of insurers. Panel A shows the results of the mean test between state-controlled and foreign insurers in the PL insurance market. We find that state-controlled PL insurance companies are significantly different from foreign ones in terms of firm age, size, level of reinsurance, diversification of products and geographic areas, and percentage of long-tail product lines. A lower level of reinsurance and higher concentration on certain product lines imply that state-controlled insurers are more inclined to take risks than their foreign counterparts. However, geographic diversification and a lower percentage of long-tail product lines imply the opposite. It is therefore difficult to assess the difference in risk preference between state-controlled and foreign insurers. Secondly, it is found that statecontrolled PL insurers have a significantly higher level of total risk and leverage risk than foreign peers.

Panel B shows the results of the mean test between state-controlled and foreign LH insurers. Like the PL insurance market, state-controlled LH insurance companies are significantly different from foreign firms in terms of firm age, size, level of reinsurance, diversification of products and geographic areas, and premium growth rates. Foreign insurers use less reinsurance, have a higher concentration in geographic areas, and are more diversified in terms of product lines. In addition, the leverage risk level of state-controlled LH insurers is significantly higher than that of foreign insurance firms. We believe the governance challenges faced by state-controlled insurers and the implicit guaranty funds possibly provide an explanation for the differences in risks between state-controlled and foreign insurers both in PL and LH insurance markets.

31 The "Ashenfelter dip" refers to the fact that the earnings of participants in training programmes tend to decline just before they start, so the "before-after" estimator would overestimate the effect of the programme (Ashenfelter, 1978). 
The Geneva Papers on Risk and Insurance-Issues and Practice

666

Table 3 Descriptive statistics of major variables

\begin{tabular}{|c|c|c|c|c|c|c|c|c|}
\hline \multirow[t]{2}{*}{ Variable } & \multicolumn{3}{|c|}{ State-controlled insurers } & \multicolumn{3}{|c|}{ Foreign insurers } & \multicolumn{2}{|c|}{ Mean test } \\
\hline & $N$ & Mean & Standard deviation & $N$ & Mean & Standard deviation & Difference & Sig. \\
\hline Age & 56 & 17.5000 & 15.2654 & 41 & 8.2593 & 2.9819 & 9.2407 & 0.0020 \\
\hline LnSize & 56 & 8.9784 & 1.3551 & 41 & 6.0733 & 0.6782 & 2.9051 & 0.0000 \\
\hline RR & 56 & 0.2340 & 0.1068 & 41 & 0.3449 & 0.2415 & -0.1109 & 0.0340 \\
\hline BHHI & 56 & 0.5524 & 0.1288 & 41 & 0.3385 & 0.0886 & 0.2138 & 0.0000 \\
\hline GHHI & 56 & 0.1209 & 0.1033 & 41 & 0.9091 & 0.2049 & -0.7883 & 0.0000 \\
\hline LONGTAIL & 56 & 0.0238 & 0.0138 & 41 & 0.2512 & 0.1801 & -0.2274 & 0.0000 \\
\hline PGR & 56 & 0.4057 & 0.6962 & 41 & 1.7230 & 6.6404 & -1.3173 & 0.2690 \\
\hline Total risk & 56 & 0.0648 & 0.0483 & 41 & 0.0449 & 0.0457 & 0.0198 & 0.1000 \\
\hline Underwriting risk & 56 & 0.1519 & 0.0958 & 41 & 0.2170 & 0.2106 & -0.0651 & 0.1470 \\
\hline Leverage risk & 56 & 0.8380 & 0.1450 & 41 & 0.4374 & 0.1105 & 0.4006 & 0.0000 \\
\hline
\end{tabular}

Panel B: LH insurance market

\begin{tabular}{|c|c|c|c|c|c|c|c|c|}
\hline \multirow[t]{2}{*}{ Variable } & \multicolumn{3}{|c|}{ State-controlled insurers } & \multicolumn{3}{|c|}{ Foreign insurers } & \multicolumn{2}{|c|}{ Mean test } \\
\hline & $N$ & Mean & Standard deviation & $N$ & Mean & Standard deviation & Difference & Sig. \\
\hline Age & 28 & 18.1667 & 17.6775 & 47 & 6.7857 & 3.1781 & 11.3810 & 0.0050 \\
\hline LnSize & 28 & 10.4929 & 2.1809 & 47 & 7.6804 & 1.6651 & 2.8126 & 0.0000 \\
\hline $\mathrm{RR}$ & 28 & 0.0339 & 0.0573 & 47 & 0.0104 & 0.0115 & 0.0235 & 0.0590 \\
\hline BHHI & 28 & 0.5654 & 0.1324 & 47 & 0.5458 & 0.1026 & 0.0196 & 0.0790 \\
\hline GHHI & 28 & 0.3011 & 0.3640 & 47 & 0.5689 & 0.3360 & -0.2679 & 0.0080 \\
\hline PGR & 28 & 0.1536 & 0.1591 & 47 & 0.6811 & 0.8176 & -0.5275 & 0.0020 \\
\hline Total risk & 28 & 0.0222 & 0.0244 & 47 & 0.0249 & 0.0149 & -0.0027 & 0.6250 \\
\hline Underwriting risk & 28 & 0.0904 & 0.0514 & 47 & 0.0787 & 0.0565 & 0.0017 & 0.4430 \\
\hline Leverage risk & 28 & 0.9292 & 0.0551 & 47 & 0.8315 & 0.1573 & 0.0977 & 0.0040 \\
\hline
\end{tabular}

Notes: AGE is the number of years since an insurer was established. LNSIZE is the natural logarithm of the total asset of insurance firms. RR is the ratio of reinsurance ceded divided by the sum of direct premiums written plus reinsurance assumed. BHHI (business line Herfindahl index) measures the line concentration, which is defined as $\sum\left(P W_{i} / T P W\right)^{2}$ where $P W_{i}$ is the value of net written premiums in line $i$ and $T P W$ is the insurer's total net written premiums. GHHI (geographic Herfindahl index) is a measure of geographic concentration defined as $\sum\left(P W_{i} / T P W\right)^{2}$, where $P W_{i}$ is the value of net written premiums in province $i$ and $T P W$ is the insurer's total net written premiums. LONGTAIL (percentage of long-tail lines) is calculated by the premiums of long-tail lines divided by total net written premiums. PGR is the growth rate of net premiums written by insurers. Total risk is defined as the standard deviation of the return on assets. The proportion of premiums written in the health business is used as a proxy for the underwriting risk for LH insurance firms, and the standard deviation of the loss ratio is a proxy for the underwriting risk of PL insurers. The loss ratio is calculated as the sum of total losses incurred (paid and reserved) in claims plus adjustment expenses divided by the total premiums earned. Leverage risk is defined as one minus the surplus-toasset ratio.

Table 4 shows the Pearson correlation coefficients of all independent variables. We find that LNSIZE (firm size), HHI (Herfindahl index), LONGTAIL (percentage of long-tail product lines) and GHHI (geographic Herfindahl index) are highly correlated with each other in the PL insurance market, and firm size, HHI and BHHI have high correlations with the other variables in the $\mathrm{LH}$ insurance market. These control variables are excluded from our 
Table 4 Correlations of independent variables

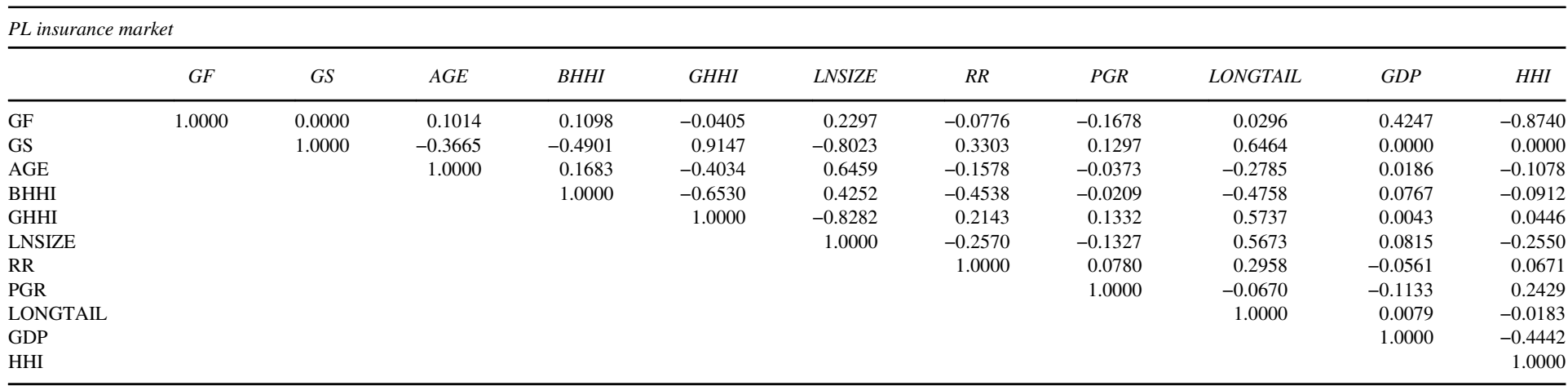

LH insurance market

\begin{tabular}{|c|c|c|c|c|c|c|c|c|c|c|}
\hline & $G F$ & $G S$ & $A G E$ & BHHI & GHHI & LNSIZE & $R R$ & $P G R$ & $G D P$ & $H H I$ \\
\hline GF & 1.0000 & 0.0000 & 0.0922 & 0.1204 & -0.1819 & 0.1852 & 0.0818 & -0.0929 & 0.1545 & -0.8103 \\
\hline GS & & 1.0000 & -0.4272 & -0.7902 & 0.3672 & -0.5889 & -0.2357 & 0.2708 & 0.0000 & 0.0000 \\
\hline AGE & & & 1.0000 & 0.2030 & -0.4314 & 0.6655 & -0.0638 & -0.1650 & 0.0169 & -0.0865 \\
\hline BHHI & & & & 1.0000 & -0.4139 & -0.8342 & -0.4016 & -0.0301 & 0.0893 & -0.0782 \\
\hline GHHI & & & & & 1.0000 & -0.9009 & -0.0175 & 0.1327 & -0.0846 & 0.1824 \\
\hline LNSIZE & & & & & & 1.0000 & -0.0136 & -0.2273 & 0.0573 & -0.1741 \\
\hline $\mathrm{RR}$ & & & & & & & 1.0000 & -0.0940 & -0.0373 & -0.0429 \\
\hline PGR & & & & & & & & 1.0000 & 0.0821 & 0.0072 \\
\hline GDP & & & & & & & & & 1.0000 & -0.2122 \\
\hline HHI & & & & & & & & & & 1.0000 \\
\hline
\end{tabular}

Notes: GF is a dummy variable for guaranty funds that takes the value of one following the establishment of explicit funds in 2005 , and zero otherwise. GS is a dummy variable for insurers' governance structure that is zero for state-controlled insurers and one for foreign firms. AGE is the number of years since an insurer was established.BHHI (business line Herfindahl index) measures product line concentration, defined as $\sum\left(P W_{i} / T P W\right)^{2}$, where $P W_{i}$ is the value of net written premiums in line $i$ and $T P W$ is the insurer's total net written premiums. GHHI (geographic Herfindahl index) is a measure of geographic concentration defined as $\sum\left(P W_{i} / T P W\right)^{2}$ where $P W_{i}$ is the net written premiums in province $i$ and $T P W$ is the insurer's total net written premiums. LNSIZE is the natural logarithm of the total assets of insurance firms. RR is the ratio of reinsurance ceded divided by the sum of direct premiums written plus reinsurance assumed. PGR is the growth rate of net premiums written by insurers. LONGTAIL (percentage of long-tail lines) is calculated by the premiums of long-tail lines divided by total net written premiums. GDP is the growth rate of GDP. HHI is the Herfindahl index of the PL or LH insurance market and is used to measure market concentration. 
models to address the problem of multicollinearity. We use variance inflation factors (VIFs) to test for multicollinearity among the independent variables in the regression design. The VIFs of all independent variables in the regressions are lower than 5, so the regression results are not adversely affected by multicollinearity.

\section{Empirical results}

We investigate the risk-subsidy and monitoring hypotheses of guaranty funds and the difference in their effect on risk taking by state-controlled and foreign insurers. First, pooled samples are used to examine the overall effect. Then, to take into account the difference in the characteristics of PL and LH insurers, we examine Models 1 and 2 for each market separately. Finally, we present a summary of the empirical results for all three markets.

\section{Pooled market}

The empirical results showing the effect of guaranty funds on risk taking using the pooled sample are presented in Table $5 .^{32}$ Model 1 investigates the effect of guaranty funds on risk taking by pooled insurers. In the pooled sample, the guaranty funds variable has a significant and negative relationship with both total and leverage risk. The risks of insurers decrease following the establishment of guaranty funds. These results support Hypothesis 2. Firm age is negatively related to total risk, but positively to leverage risk. Insurers with a longer history become more sophisticated and have the capacity to maintain a stable operation. The reinsurance ratio has a significant and negative relationship with both total and leverage risk. A higher growth rate of premiums leads to a higher level of both risk types. The growth rate of GDP has a positive relationship with total risk, but a negative one with leverage risk. An explanation for this is that the rapid growth of an economy creates more investment opportunities for insurers. In particular, they are attracted to investing more in stocks as the securities market booms, which leads to a higher total risk. On the other hand, the Chinese financial industry has been gradually opened up to the domestic private sector. It has become easier for insurance companies to access capital. Hence, the average level of the leverage ratio tends to decline.

Model 2 investigates the difference in the effect of guaranty funds on risk taking between state-controlled and foreign insurers. It can be seen that total and leverage risk both decrease following the establishment of guaranty funds. State-controlled insurers have significantly lower total risk than their foreign competitors. Foreign insurers are more risk-driven than state-controlled insurers following the establishment of guaranty funds, which supports Hypothesis 3. The establishment of guaranty funds provides protection against excessive risk taking by foreign insurers. Firm age has a negative relationship with total and leverage risk. Reinsurance significantly reduces insurers' leverage risk. Insurers with higher growth rate of premiums have more leverage risk. The growth rate of GDP has a positive relationship with an insurer's total risk and a negative relationship with leverage risk.

\footnotetext{
${ }^{32}$ In the pooled sample, the relationship between guaranty funds and the underwriting risks of insurers is not tested for the distinct measures of underwriting risks that are adopted for PL and LH insurers.
} 
Table 5 Regression results of guaranty funds on risk taking by pooled insurers

\begin{tabular}{|c|c|c|c|c|c|c|c|c|}
\hline \multirow[t]{3}{*}{ Variable } & \multicolumn{4}{|c|}{ Total risk } & \multicolumn{4}{|c|}{ Leverage risk } \\
\hline & \multicolumn{2}{|c|}{ Model 1} & \multicolumn{2}{|c|}{ Model 2} & \multicolumn{2}{|c|}{ Model 1} & \multicolumn{2}{|c|}{ Model 2} \\
\hline & Coefficient & Prob. & Coefficient & Prob. & Coefficient & Prob. & Coefficient & Prob. \\
\hline $\mathrm{C}$ & 0.1270 & 0.0000 & -0.0819 & 0.0000 & -0.5415 & 0.0000 & 2.1836 & 0.0000 \\
\hline GF & $-0.0010 * * *$ & 0.0000 & $-0.0029 * * *$ & 0.0000 & $-0.0149 * * *$ & 0.0000 & $-0.0132 * *$ & 0.0305 \\
\hline GS & & & $-0.0362 * * *$ & 0.0000 & & & 0.0625 & 0.3437 \\
\hline $\mathrm{GF} \times \mathrm{GS}$ & & & $0.0105^{* * *}$ & 0.0000 & & & -0.0422 & 0.1031 \\
\hline AGE & $-0.0205 * * *$ & 0.0000 & $-0.0004^{*}$ & 0.0570 & $0.2913 * * *$ & 0.0000 & $-0.0039 * * *$ & 0.0080 \\
\hline $\mathrm{RR}$ & $-0.0272 * * *$ & 0.0005 & -0.0238 & 0.1328 & $-0.2743 * * *$ & 0.0000 & $-0.3528 * * *$ & 0.0000 \\
\hline PGR & $0.0004 * * *$ & 0.0000 & 0.0002 & 0.5247 & $0.0059 * * *$ & 0.0000 & $0.0053^{*}$ & 0.0587 \\
\hline GDP & $1.4707 * * *$ & 0.0000 & $0.6000 * * *$ & 0.0000 & $-19.4226 * * *$ & 0.0000 & $-6.1533 * * *$ & 0.0000 \\
\hline$R^{2}$ & 0.9579 & & 0.9146 & & 0.9750 & & 0.9181 & \\
\hline Adjusted $R^{2}$ & 0.9402 & & 0.9055 & & 0.9648 & & 0.9094 & \\
\hline F-statistic & $56.1667 * * *$ & & $101.2587 * * *$ & & $96.1269 * * *$ & & $99.8705 * * *$ & \\
\hline Durbin-Watson stat & 2.08 & & 2.0447 & & 1.80 & & 1.6277 & \\
\hline Observations & 172 & & 172 & & 172 & & 172 & \\
\hline
\end{tabular}

Notes: Model 1 examines the effect of explicit guaranty funds on risk taking by pool insurers. Model 2 examines the difference in the effect of guaranty funds on risk taking between state-controlled and foreign insurers in a pooled market. $C$ is the intercept of the regression models. GF is a dummy variable for guaranty funds that takes the value of one following the establishment of explicit guaranty funds in 2005, and zero otherwise. GS is a binary dummy variable denoting the governance structure of insurers. State-controlled insurers are the control group for which GS equals zero, while foreign insurers are the treatment group for which GS is set to one. AGE denotes the number of years since an insurer was established. RR is the ratio of reinsurance ceded divided by the sum of direct premiums written plus reinsurance assumed. PGR is the growth rate of net premiums written by insurers. GDP is the growth rate of GDP. Total risk is defined as the standard deviation of return on assets. Leverage risk is defined as one minus the surplus-to-assets ratio.

Model 1 is a fixed-effects model. Model 2 uses 2SLS regression. The location of the firm's head office at the time of establishment is used as the instrumental variable to represent the ownership structure variable GS. Heteroscedasticity-robust $t$-test is used.

$* * *, * *$ and $*$ represent statistical significance at the $0.01,0.05$ and 0.1 levels, respectively.

\section{The PL insurance market}

The empirical results showing the relationship between guaranty funds and risk taking by PL insurers are presented in Table 6. We find that guaranty funds are negatively related to total, underwriting and leverage risk. This provides evidence for the monitoring hypothesis. That is, monitoring from stakeholders and regulators dominates the risk incentive to insurers following the establishment of guaranty funds. Firm age has a negative relationship with total and underwriting risk, but a positive one with leverage risk. We observe that the business Herfindahl index is positively related to total and underwriting risk. Higher concentration on product lines tends to increase risk levels. The reinsurance ratio has a negative relationship with risks. Reinsurance significantly reduces insurers' total, underwriting and leverage risk. The premium growth rate is positively related to total and leverage risk. The growth rate of GDP is positively related to total and underwriting risk, but negatively to leverage risk, which is consistent with the results of the pooled market sample. 
Table 6 Regression results of guaranty funds on risk taking by PL insurers

\begin{tabular}{|c|c|c|c|c|c|c|}
\hline \multirow[t]{2}{*}{ Variable } & \multicolumn{2}{|c|}{ Total risk } & \multicolumn{2}{|c|}{ Underwriting risk } & \multicolumn{2}{|c|}{ Leverage risk } \\
\hline & Coefficient & Prob. & Coefficient & Prob. & Coefficient & Prob. \\
\hline $\mathrm{C}$ & 0.1294 & 0.0000 & 0.6278 & 0.0001 & -0.0540 & 0.3411 \\
\hline GF & $-0.0036^{* * *}$ & 0.0000 & $-0.0932 * * *$ & 0.0000 & $-0.0088 * * *$ & 0.0040 \\
\hline AGE & $-0.0257 * * *$ & 0.0000 & $-0.1574 * * *$ & 0.0005 & $0.1446^{* * *}$ & 0.0000 \\
\hline BHHI & $0.0908 * * *$ & 0.0000 & $0.4773 * * *$ & 0.0000 & -0.1473 & 0.3594 \\
\hline $\mathrm{RR}$ & $-0.0185^{* * *}$ & 0.0039 & $-0.1248 * * *$ & 0.0000 & $-0.2887 * * *$ & 0.0000 \\
\hline PGR & $0.0002 * * *$ & 0.0023 & 0.0012 & 0.5341 & $0.0059 * * *$ & 0.0000 \\
\hline GDP & $1.9018 * * *$ & 0.0000 & $11.8146^{* * *}$ & 0.0003 & $-8.7228 * * *$ & 0.0000 \\
\hline$R^{2}$ & 0.9673 & & 0.7298 & & 0.9695 & \\
\hline Adjusted $R^{2}$ & 0.9505 & & 0.5913 & & 0.9538 & \\
\hline F-statistic & $57.6482 * * *$ & & $5.2682 * * *$ & & $61.9576 * * *$ & \\
\hline Durbin-Watson stat & 2.0347 & & 2.0161 & & 2.1451 & \\
\hline Observations & 97 & & 97 & & 97 & \\
\hline
\end{tabular}

Notes: The table shows the regression results of Model 1 that examines the effect of explicit guaranty funds on risk taking by PL insurers. $C$ is the intercept of the regression models. GF is a dummy variable for guaranty funds that takes the value of one following their establishment in 2005, and zero otherwise. AGE is the number of years since an insurer was established. BHHI (business line Herfindahl index) measures the line concentration, which is defined as $\sum\left(P W_{i} / T P W\right)^{2}$ where $P W_{i}$ is the value of the net written premiums in line $i$ and $T P W$ is the insurer's total net written premiums. RR is the ratio of reinsurance ceded divided by the sum of direct premiums written plus reinsurance assumed. PGR is the growth rate of the net premiums written by insurers. GDP is the growth rate of the GDP. Total risk is defined as the standard deviation of the return on assets. The standard deviation of the loss ratio is a proxy for the underwriting risk of PL insurers. The loss ratio is calculated as the sum of total losses incurred (paid and reserved) in claims plus adjustment expenses divided by the total premiums earned. Leverage risk is defined as one minus the surplus-to-asset ratio.

All models are fixed-effects models. $* * *, * *$ and $*$ represent statistical significance at the $0.01,0.05$ and 0.1 levels, respectively.

Table 7 shows the results of Model 2, which investigates the difference in the effect of guaranty funds on risk taking for state-controlled and foreign insurers in the PL market. The underwriting risk is negatively related to the variable representing guaranty funds. State-controlled PL insurers have higher levels of total and leverage risk than foreign insurers, while the latter take on more underwriting risk. In terms of the influence of ownership structure on the effect of funds on risk taking, we find that foreign PL insurers are more risk-driven for leverage risk, which supports Hypothesis 3. However, the results for underwriting risk suggest that state-controlled insurers are more risk-driven following the establishment of guaranty funds. One possible explanation for this is the complete removal of restrictions on product lines and geographic spread in 2006, which contributed to the business and geographic diversification of foreign insurance companies and led, in turn, to a decrease in the underwriting risk. Meanwhile, the underwriting quality of state-controlled insurers was declining after several years of the implementation of a "volume expansion" strategy. The combined effect of these events may explain the finding that state-controlled insurers are more risk-driven in terms of underwriting behaviour.

We observe that the reinsurance ratio is negatively related to the total and leverage risk, consistent with expectations. Premium growth rate is positively related to underwriting and 
Table 7 Differences in the effect of guaranty funds on risk taking between state-controlled and foreign PL insurers

\begin{tabular}{|c|c|c|c|c|c|c|}
\hline \multirow[t]{2}{*}{ Variable } & \multicolumn{2}{|c|}{ Total risk } & \multicolumn{2}{|c|}{ Underwriting risk } & \multicolumn{2}{|c|}{ Leverage risk } \\
\hline & Coefficient & Prob. & Coefficient & Prob. & Coefficient & Prob. \\
\hline $\mathrm{C}$ & -0.0588 & 0.5513 & 0.0631 & 0.2981 & 0.9172 & 0.0000 \\
\hline GF & -0.0019 & 0.5629 & $-0.0322 * *$ & 0.0338 & -0.0068 & 0.2609 \\
\hline GS & $-0.0645^{*}$ & 0.0970 & $0.1203 * *$ & 0.0190 & $-0.4844 * * *$ & 0.0000 \\
\hline $\mathrm{GF} \times \mathrm{GS}$ & 0.0070 & 0.4000 & $-0.1554 * * * *$ & 0.0000 & $0.0364 * *$ & 0.0189 \\
\hline AGE & $-0.0019 * * *$ & 0.0102 & $-0.0020 * * *$ & 0.0026 & $-0.0017 * * *$ & 0.0002 \\
\hline BHHI & 0.0046 & 0.5515 & 0.0705 & 0.6358 & -0.1214 & 0.2378 \\
\hline $\mathrm{RR}$ & $-0.0738 * * *$ & 0.0024 & -0.0382 & 0.3822 & $-0.1958^{* *}$ & 0.0302 \\
\hline PGR & 0.0000 & 0.7562 & $0.0025^{*}$ & 0.0684 & $0.0224 * * *$ & 0.0000 \\
\hline GDP & $0.9808 * *$ & 0.0318 & $0.8292 * * *$ & 0.0083 & $0.7340 * * *$ & 0.0000 \\
\hline$R^{2}$ & 0.9512 & & 0.3479 & & 0.9334 & \\
\hline Adjusted $R^{2}$ & 0.9387 & & 0.2456 & & 0.9163 & \\
\hline F-statistic & $77.3256^{* * * *}$ & & $5.5575 * * *$ & & $56.1244 * * *$ & \\
\hline Durbin-Watson stat & 2.1491 & & 1.4968 & & 1.9375 & \\
\hline Observations & 97 & & 97 & & 97 & \\
\hline
\end{tabular}

Notes: The table shows the results of Model 2 that investigates the effect of guaranty funds on risk taking by PL insurers with different ownership structures. $C$ is the intercept of the regression models. GF is a dummy variable for guaranty funds that takes the value of one following their establishment in 2005, and zero otherwise. GS is a binary dummy variable denoting the governance structure of insurers; state-controlled insurers are the control for which GS equals zero, while the foreign insurers are the treatment group for which GS is one. AGE is the number of years since an insurer was established. BHHI (business Herfindahl index) measures the line concentration, which is defined as $\sum\left(P W_{i} / T P W\right)^{2}$, where $P W_{i}$ is the value of the net written premiums in line $i$ and $T P W$ is the insurer's total net written premiums. RR is the ratio of reinsurance ceded divided by the sum of direct premiums written plus reinsurance assumed. PGR is the growth rate of the net premiums written by insurers. GDP is the growth rate of the GDP.

Total risk is defined as the standard deviation of the return on assets. The standard deviation of the loss ratio is a proxy for the underwriting risk of PL insurers. The loss ratio is calculated by the sum of total losses incurred (paid and reserved) in claims plus adjustment expenses divided by the total premiums earned. Leverage risk is defined as one minus the surplus-to-asset ratio.

2SLS regression is used. The location of the firm's head office at the time of establishment is used as the instrumental variable for the ownership structure variable GS. Heteroscedasticity-robust $t$ test is used. $* * *, * *$ and $*$ represent statistical significance at the $0.01,0.05$ and 0.1 levels, respectively.

leverage risk. The growth rate of GDP is also positively related to total, underwriting and leverage risk.

\section{The LH insurance market}

The empirical analysis of the relationship between guaranty funds and risk taking by $\mathrm{LH}$ insurance companies is shown in Table 8. Total and underwriting risk have a significant and negative relationship with guaranty funds. LH insurance companies' risks decrease following the establishment of these funds. These results are evidence for the monitoring hypothesis, as for the PL insurance market. There is no significant negative relationship between leverage risk and guaranty funds. Firm age is found to be positively related to leverage risk. GHHI is positively related to total risk and negatively to leverage risk. The reinsurance ratio has a significant negative relationship with both total and leverage risk. The premium growth rate is 
Table 8 Regression results of guaranty funds on risk taking by LH insurers

\begin{tabular}{|c|c|c|c|c|c|c|}
\hline \multirow[t]{2}{*}{ Variable } & \multicolumn{2}{|c|}{ Total risk } & \multicolumn{2}{|c|}{ Underwriting risk } & \multicolumn{2}{|c|}{ Leverage risk } \\
\hline & Coefficient & Prob. & Coefficient & Prob. & Coefficient & Prob. \\
\hline $\mathrm{C}$ & 0.0268 & 0.0000 & 0.0365 & 0.3483 & -0.1721 & 0.5230 \\
\hline GF & $-0.0071 * * *$ & 0.0000 & $-0.0291 * * *$ & 0.0000 & -0.0054 & 0.6649 \\
\hline AGE & 0.0019 & 0.4149 & -0.0063 & 0.5019 & 0.3281 *** & 0.0001 \\
\hline GHHI & $0.0100 * *$ & 0.0118 & 0.0018 & 0.9086 & $-0.1726^{* *}$ & 0.0032 \\
\hline $\mathrm{RR}$ & $-0.0719 * * *$ & 0.0006 & 0.0295 & 0.3118 & $-0.4299 * *$ & 0.0236 \\
\hline PGR & -0.0002 & 0.9134 & $-0.0100 * * *$ & 0.0000 & $-0.0283^{*}$ & 0.0542 \\
\hline GDP & -0.2512 & 0.1699 & 1.1034 & 0.1095 & $-23.2025 * * *$ & 0.0001 \\
\hline$R^{2}$ & 0.8631 & & 0.9441 & & 0.8393 & \\
\hline Adjusted $R^{2}$ & 0.7885 & & 0.9136 & & 0.7517 & \\
\hline F-statistic & $11.5616^{* * *}$ & & $30.9469 * * *$ & & $9.5782 * * *$ & \\
\hline Durbin-Watson stat & 1.9596 & & 1.7778 & & 1.7182 & \\
\hline Observations & 75 & & 75 & & 75 & \\
\hline
\end{tabular}

Notes: The table shows the regression results of Model 1 that examines the effect of explicit guaranty funds on risk taking by LH insurers. $C$ is the intercept of the regression models. GF is a dummy variable for guaranty funds that takes the value of one following their establishment in 2005 and zero otherwise. AGE is the number of years since an insurer was established. GHHI (geographic Herfindahl index) measures the geographic concentration of business, defined as $\sum\left(P W_{i} / T P W\right)^{2}$, where $P W_{i}$ is the value of net written premiums in province $i$ and $T P W$ is the insurer's total net written premiums. RR is the ratio of reinsurance ceded divided by the sum of direct premiums written plus reinsurance assumed. PGR is the growth rate of the net premiums written by insurers. GDP is the growth rate of GDP.

Total risk is defined as the standard deviation of the returns on asset. The proportion of premiums written in the health business is used as a proxy for the underwriting risk, following Cheng et al. (2011). Leverage risk is defined as one minus the surplus-to-asset ratio.

All models are fixed-effects models. $* * *, * *$ and $*$ represent statistical significance at the $0.01,0.05$ and 0.1 levels, respectively.

negatively related to underwriting and leverage risk. The LH insurers' premiums stems mainly from life insurance products, such as participating insurance. Hence, the ratio of premiums written for their health insurance products declines even though the growth rate of their total written premiums increases. The growth rate of GDP is negatively linked to the leverage risk, as also observed in the pooled and PL insurance markets.

Table 9 sets out the empirical results of Model 2, looking at the different effect of guaranty funds on risk taking between state-controlled and foreign LH insurers. It can be seen that both the total and underwriting risk of LH insurers decreases with the establishment of guaranty funds, supporting Hypothesis 1 . Foreign LH insurers have a higher total risk than state-controlled insurers. Following the establishment of guaranty funds, foreign LH insurers become more risk-driven in terms of total and leverage risk, providing evidence for Hypothesis 3. We observe that firm age is negatively related to underwriting and leverage risk, which is consistent with the results from the PL insurance market. GHHI has a positive relationship to total risk. The reinsurance ratio is negatively related to leverage risk, as also observed in the pooled and PL insurance markets. The growth rate of premiums has a positive relationship with total risk and a negative one with underwriting risk. The growth rate of GDP is positively linked to total risk, but negatively to leverage risk, again as found for the pooled insurance market. 
Table 9 Difference in the effect of guaranty funds on risk taking between state-controlled and foreign LH insurers

\begin{tabular}{|c|c|c|c|c|c|c|}
\hline \multirow[t]{2}{*}{ Variable } & \multicolumn{2}{|c|}{ Total risk } & \multicolumn{2}{|c|}{ Underwriting risk } & \multicolumn{2}{|c|}{ Leverage risk } \\
\hline & Coefficient & Prob. & Coefficient & Prob. & Coefficient & Prob. \\
\hline $\mathrm{C}$ & -0.0033 & 0.5566 & 0.0465 & 0.6354 & 1.4707 & 0.0000 \\
\hline GF & $-0.0017 *$ & 0.0568 & $-0.0205^{*}$ & 0.0219 & 0.0014 & 0.7054 \\
\hline GS & $0.0022 * *$ & 0.0460 & -0.0003 & 0.9963 & -0.0036 & 0.4957 \\
\hline $\mathrm{GF} \times \mathrm{GS}$ & $0.0076 * * *$ & 0.0000 & -0.0121 & 0.4373 & $0.0251 * * *$ & 0.0000 \\
\hline AGE & 0.0000 & 0.4543 & $-0.0011^{*}$ & 0.0873 & $-0.0024 * * *$ & 0.0000 \\
\hline GHHI & $0.0164 * * *$ & 0.0000 & 0.0312 & 0.6366 & -0.0549 & 0.1201 \\
\hline $\mathrm{RR}$ & -0.0401 & 0.2483 & 0.0111 & 0.5494 & $-0.2397 * * *$ & 0.0000 \\
\hline PGR & $0.0027 * * *$ & 0.0020 & $-0.0107 * * *$ & 0.0026 & -0.0024 & 0.2407 \\
\hline GDP & $0.0839 * *$ & 0.0481 & 0.5160 & 0.2785 & $-3.5751 * * *$ & 0.0000 \\
\hline$R^{2}$ & 0.8461 & & 0.8957 & & 0.9939 & \\
\hline Adjusted $R^{2}$ & 0.7983 & & 0.8634 & & 0.9920 & \\
\hline F-statistic & $16.8714 * * *$ & & $27.6025 * * *$ & & $504.1215^{* * *}$ & \\
\hline Durbin-Watson stat & 1.8800 & & 2.3705 & & 1.9184 & \\
\hline Observations & 75 & & 75 & & 75 & \\
\hline
\end{tabular}

Notes: The table shows the results of Model 2 that examines the effect of guaranty funds on risk taking by LH insurers with different ownership structures. $C$ is the intercept of the regression models. GF is a dummy variable for guaranty funds that takes the value of one following their establishment in 2005 and zero otherwise. GS is a binary dummy variable denoting the governance structure of insurers; state-controlled insurers are the control for which GS equals zero, while the foreign insurers are the treatment group for which GS is one. AGE is the number of years since an insurer was established. GHHI (geographic Herfindahl index) measures the geographic concentration, defined as $\sum\left(P W_{i} / T P W\right)^{2}$ where $P W_{i}$ is the values of net written premiums in province $i$ and $T P W$ is the insurer's total net written premiums. RR is the ratio of reinsurance ceded divided by the sum of direct premiums written plus reinsurance assumed. PGR is the growth rate of the net premiums written by insurers. GDP is the growth rate of GDP.

Total risk is defined as the standard deviation of return on assets. The proportion of premiums written in the health business is used as a proxy for the underwriting risk, following Cheng et al. (2011). Leverage risk is defined as one minus the surplus-to-asset ratio.

2SLS regression is used. The location of the firm's head office at the time of establishment is used as the instrumental variable for the ownership structure variable GS. Heteroscedasticity-robust $t$ test is used. $* * *, * *$ and $*$ represent statistical significance at the $0.01,0.05$ and 0.1 levels, respectively

\section{Summary of main empirical results}

So far, we have examined the risk-subsidy, monitoring and ownership structure hypotheses by using samples drawn from the Chinese insurance industry. Here, we draw out the most significant empirical results from Models 1 and 2 to draw our conclusions.

Table 10 summarises the key results from Tables 5-9. Panel A shows that, following the establishment of guaranty funds, insurers took fewer risks whether we look at the pooled market or the PL or LH segments. The results favour the monitoring hypothesis and meet the expectations of policymakers. Chinese guaranty funds with their pre-assessment mechanism provide only a small risk incentive that can be offset by stakeholder monitoring. In practice, pre-assessment has proven to be an alternative to mitigating the risk-subsidy incentive to insurers. This is consistent with the finding that the introduction of explicit deposit insurance in the EU has significantly reduced banks' risk taking. ${ }^{28}$ 
The Geneva Papers on Risk and Insurance-Issues and Practice

674

Table 10 Summary of significant results

\begin{tabular}{|c|c|c|c|c|c|c|c|c|}
\hline \multirow[t]{2}{*}{ Variable } & \multicolumn{2}{|c|}{ Pool market } & \multicolumn{3}{|c|}{ PL insurance market } & \multicolumn{3}{|c|}{ LH insurance market } \\
\hline & $\begin{array}{l}\text { Total } \\
\text { risk }\end{array}$ & $\begin{array}{l}\text { Leverage } \\
\text { risk }\end{array}$ & $\begin{array}{c}\text { Total } \\
\text { risk }\end{array}$ & $\begin{array}{c}\text { Underwriting } \\
\text { risk }\end{array}$ & $\begin{array}{c}\text { Leverage } \\
\text { risk }\end{array}$ & $\begin{array}{c}\text { Total } \\
\text { risk }\end{array}$ & $\begin{array}{c}\text { Underwriting } \\
\text { risk }\end{array}$ & $\begin{array}{c}\text { Leverage } \\
\text { risk }\end{array}$ \\
\hline GF & - & - & - & - & - & - & - & \\
\hline $\begin{array}{l}\text { AGE } \\
\text { BHHI }\end{array}$ & - & + & - & - & + & & & + \\
\hline /GHHI & & & + & + & & + & & - \\
\hline $\mathrm{RR}$ & - & - & - & - & - & - & & - \\
\hline PGR & + & + & + & & + & & - & - \\
\hline GDP & + & - & + & + & - & & & - \\
\hline
\end{tabular}

Panel B: Model 2 difference in the effect of guaranty funds on risk taking between state-controlled and foreign insurers

\begin{tabular}{|c|c|c|c|c|c|c|c|c|}
\hline \multirow[t]{2}{*}{ Variable } & \multicolumn{2}{|c|}{ Pool market } & \multicolumn{3}{|c|}{$P L$ insurance market } & \multicolumn{3}{|c|}{ LH insurance market } \\
\hline & $\begin{array}{c}\text { Total } \\
\text { risk }\end{array}$ & $\begin{array}{l}\text { Leverage } \\
\quad \text { risk }\end{array}$ & $\begin{array}{l}\text { Total } \\
\text { risk }\end{array}$ & $\begin{array}{l}\text { Underwriting } \\
\text { risk }\end{array}$ & $\begin{array}{l}\text { Leverage } \\
\quad \text { risk }\end{array}$ & $\begin{array}{c}\text { Total } \\
\text { risk }\end{array}$ & $\begin{array}{l}\text { Underwriting } \\
\text { risk }\end{array}$ & $\begin{array}{l}\text { Leverage } \\
\text { risk }\end{array}$ \\
\hline GF & - & - & & - & & - & - & \\
\hline GS & - & & - & + & - & + & & \\
\hline $\mathrm{GF} \times \mathrm{GS}$ & + & & & - & + & + & & + \\
\hline AGE & - & - & - & - & - & & - & - \\
\hline $\begin{array}{l}\text { BHHI } \\
\text { /GHHI }\end{array}$ & & & & & & + & & \\
\hline $\mathrm{RR}$ & & - & - & & - & & & - \\
\hline PGR & & + & & + & + & + & - & \\
\hline GDP & + & - & + & + & + & + & & - \\
\hline
\end{tabular}

The evidence in Panel B suggests the conclusion that foreign insurers are more riskdriven, which supports Hypothesis 3. With the establishment of guaranty funds, foreign insurance firms became covered by a safety net. The shift provided them with more risk incentives than their state-controlled counterparts, who had always benefited from protection against takeover and bankruptcy. The regression results of the underwriting risk in the PL insurance market shows the opposite trend. One explanation for this is that the implementation of China's commitment to the WTO has helped the diversification of foreign insurers, leading to a decline in their underwriting risk, while state-controlled insurers have suffered more from their volume expansion strategy.

From the results of Models 1 and 2, it can be seen that older firms are prone to take fewer risks. The more concentrated a firm is on particular product lines or locations, the more risks it takes. Reinsurance significantly reduces the risk to insurance companies. Generally, the rapid growth of written premiums tends to increase insurers' risks. Chinese economic prosperity has led to a booming financial market where insurers tend to invest more in stocks, resulting in higher total risk. On the other hand, the greater amount of capital available to insurers helps decrease leverage risk. 
We used an alternative variable, ownership structure, to test the robustness of the results from Model 2. Ownership structure can be measured in an alternative way as one minus the percentage of state shareholding, which is a continuous variable. We regressed Model 2 using the continuous variable with all other variables unchanged. The empirical results showed that the coefficients of the guaranty funds were negative and of the cross term positive, except for the underwriting risk model in the PL insurance market. Hence, we believe our results are robust.

\section{Conclusions}

In this study, we have examined the risk-subsidy, monitoring and ownership structure hypotheses for guaranty funds using a sample drawn from the Chinese insurance industry. Chinese guaranty funds have similar features to those found elsewhere, such as a benefit cap for policyholders, a flat-rate assessment and the exclusion of reinsurance and overseas business. However, compared to the American model, Chinese insurance guaranty funds have the following special features: (1) pre-assessment: the guaranty fund of every insurance firm operating in China is assessed annually; (2) separate accumulation: the guaranty funds collected from each insurer are not pooled before use, with funds accumulated under a nominal account for each insurer; (3) partial responsibility for peer bankruptcy. When an insurer gets into financial trouble or goes bankrupt, policyholders' outstanding claims are firstly recovered from the funds accumulated in its nominal account. If this does not achieve full recovery, peers are then responsible for the shortfall, based on their percentage of market share. The discrepancy in these institutional features results in guaranty funds having different effects on risk taking by insurers.

We show that the risk taking by Chinese insurance firms declined following the establishment of guaranty funds. The ex ante funding system and the separate accumulation of funds made each insurer responsible for all or most of the cost of taking excessive risks. Pre-assessment provides little risk incentive to insurers that is easily offset by stakeholders monitoring.

With respect to the governance structure hypothesis, we find that foreign insurers are more risk-driven than their state-controlled counterparts. It is often said that state-controlled insurers are protected from the two major threats that face private sector corporations: takeover and bankruptcy. Guaranty funds as a put option have less value to state-controlled insurers. Meanwhile, foreign insurers have also suffered greatly from fierce competition for market share and would be expected to take more risky strategies to seize the market. The establishment of explicit guaranty funds provides protection for such risk taking. Therefore, foreign insurers demonstrate more risk-driven behaviour following the establishment of guaranty funds.

The results of our study imply that ex ante assessment could be an institutional option for countries striving to lessen the adverse effects of guaranty funds by adjusting their institutional features. The availability of ex ante funding can also ensure faster payout and provide greater reassurance to policyholders. Furthermore, the finding that foreign insurers are more risk-driven has implications for the development of Chinese domestic regulation policy. State-controlled insurers dominate the Chinese insurance market. Insurance regulators have always applied more supervision to state-controlled than foreign insurers. Our findings suggest that Chinese regulators should monitor foreign insurers more than they have done to date in order to create a stable and equally competitive market. 
676

\section{Acknowledgements}

The authors are grateful to Wenjiong He, Chengguo Weng, Ken Seng Tan and two anonymous referees for many helpful comments and suggestions. Financial support from the Zhejiang Social Security Research and Development Center is gratefully acknowledged. They are responsible for all shortcomings.

\section{References}

Alston, L.J., Grove, W.A. and Wheelock, D.C. (1994) 'Why do banks fail? Evidence from the 1920s', Explorations in Economic History 31(4): 409-431.

Angkinand, A. and Wihlborg, C. (2010) 'Deposit insurance coverage, ownership and banks' risk-taking in emerging markets', Journal of International Money and Finance 29(2): 252-274.

Ashenfelter, O. (1978) 'Estimating the effect of training program on earnings', Review of Economics and Statistics 60(1): 47-57.

Cawley, J. and Simon, K.I. (2003) Health insurance coverage and the macroeconomy, ERIU working paper 24, Anne Arbor, MI: Economic Research Initiative on the Uninsured, from www.umich.edu/ eriu/ pdf/wp24.pdf, accessed 7 December 2011.

Cheng, J., Elyasiani, E. and Jia, J. (2011) 'Institutional ownership stability and risk taking: Evidence from the lifehealth insurance industry', The Journal of Risk and Insurance 78(3): 609-641.

Cummins, D.J. (1988) 'Risk-based premiums for insurance guaranty funds', Journal of Finance 43(4): 823-839.

Demirgüç-Kunt, A. and Detragiache, E. (2002) 'Does deposit insurance increase banking system stability? An empirical investigation', Journal of Monetary Economics 49(7): 1373-1406.

Downs, D.H. and Sommer, D.W. (1999) 'Monitoring, ownership and risk-taking: The impact of guaranty funds', The Journal of Risk and Insurance 66(3): 477-497.

Financial Stability Board (2012) Thematic review on deposit insurance systems, from www.financialstabilityboard. org/publications/r_120208.pdf, accessed 8 March 2013.

Gropp, R. and Vesala, J.M. (2004) Deposit insurance, moral hazard and market monitoring, from www.papers.ssrn. com/sol3/papers.cfm?abstract_id=299403, accessed 4 May 2012.

Ho, C.L., Lai, G.C. and Lee, J.P. (2013) 'Organizational structure, board composition and risk taking in the U.S. property casualty insurance industry', The Journal of Risk and Insurance 80(1): 169-203.

Karels, G.V. and McClatchey, C.A. (1999) 'Deposit insurance and risk-taking behavior in the credit union industry', Journal of Banking \& Finance 23(1): 105-134.

Lee, S.J., Mayers, D. and Smith, C.W. (1997) 'Guaranty funds and risk-taking: Evidence from the insurance industry', Journal of Financial Economics 44(1): 3-24.

Merton, R.C. (1977) 'An analytic derivation of the cost of deposit insurance and loan guarantees: an application of modern option pricing theory', Journal of Banking and Finance 1(1): 3-11.

Munch, P. and Smallwood, D.E. (1980) 'Solvency regulation in the property-liability insurance industry: Empirical evidence', The Bell Journal of Economics 11(1): 261-279.

National Conference of Insurance Guaranty Funds (2011) Review of Property and Casualty Insurance Guaranty Fund Expenses 2005-2007, Indianapolis, from www.ncigf.org/media/files/Final\%20GA\%20Expense\%20Report \%2011-28-07-3.pdf, accessed 7 March 2013.

OECD (2005) OECD guidelines on corporate governance of state-owned enterprises, from www.oecd.org/daf/cal corporategovernanceofstate-ownedenterprises/34803211.pdf, accessed 17 December 2012.

Outreville, F.J. (1996) 'Life insurance markets in developing countries', The Journal of Risk and Insurance 63(2): 263-278.

Penas, M.F. and Ioannidou, V.P. (2008) Deposit Iinsurance and bank risk-taking: Evidence from internal loan ratings, from www.ssrn.com/abstract $=1102199$, accessed 8 March 2013.

Sun, Q. (2003) 'The impact of WTO accession on China's insurance industry', Risk Management and Insurance Review 6(1): 27-35.

Wheelock, D.C. and Wilson, P.W. (1995) 'Explaining bank failures: Deposit insurance, regulation, and efficiency', The Review of Economics and Statistics 77(4): 689-700. 


\section{About the Authors}

Hong Shi is a lecturer of risk management and insurance at Zhejiang University, Hangzhou, China. Her research interests include the analysis of insurance regulation, insurance market efficiency, and agricultural insurance, among others. She has published more than 10 articles in peer-reviewed journals.

Shizhe Bao is a graduate student at the University of Dallas, Texas.

cc (7) This work is licensed under a Creative Commons Attribution 3.0 Unported License. The images or other third party material in this article are included in the article's Creative Commons license, unless indicated otherwise in the credit line; if the material is not included under the Creative Commons license, users will need to obtain permission from the license holder to reproduce the material. To view a copy of this license, visit http://creativecommons.org/licenses/by/3.0/ 